\title{
WIELICIAN FORAMINIFERA AT THE WESTERN BORDER OF THE TRANSYLVANIAN BASIN
}

\author{
SORIN FILIPESCU ${ }^{1}$
}

\begin{abstract}
Marine Middle Miocene deposits at the top of Gârbova de Sus Formation preserve a particular foraminifera assemblage, with both benthic and planktonic taxa. Presence of several biostratigraphic significant species allowed an extension of the known age of the formation, up to Wielician. The morphogroups also suggest a deeper environment, compared to the rest of the formation. The change of fauna type at this level might be correlated to the start of a new global cycle.
\end{abstract}

Keywords: foraminifera, Wielician, Paratethys, Transylvanian Basin, biostratigraphy, paleoecology

\section{INTRODUCTION}

Most of the geological formations from the western border of the Transylvanian Basin were deposited during the Middle Miocene. The Lower Badenian, shallow water marine sediments, were described as Gârbova de Sus Formation (Filipescu \& Gîrbacea, 1994).

Although several sections are representative for the main stratigraphic and paleontologic features, the section from Lopadea Veche, situated about $5 \mathrm{~km}$ northwest of the E60 European road, close to the city of Aiud (Fig. 1), is of a particular interest. It was originally designed as parastratotype for the upper part of the above-mentioned formation. Recent investigations at the top of the Buhii Creek section, based on foraminifera assemblages, allowed some new interpretations on the age and the environmental changes.

The sediments in the Buhii Creek section are mainly carbonatic, dominated by algal - bioclastic structures. The lower part of the sequence, transgressively deposited over Jurassic volcanic rocks, starts with clastic deposits. Towards its upper part, the sequence is constantly regressive, characterized by algal nodular limestones. Fine sediments, which suggest a facies change occur at the top of the formation. These sediments, not more than $2 \mathrm{~m}$ thick, also have a valuable micropaleontologic record.

More information on the Badenian deposits from Lopadea Veche can be found in the contributions of Pávay-Vajna (1910), Bucur \& Filipescu $(1994,2001)$, Filipescu (1996), Şuraru (1992).

1 "Babeş-Bolyai" University, Department of Geology. Str. Kogălniceanu 1, RO-3400 Cluj-Napoca, Romania. E-mail: sorin@bioge.ubbcluj.ro 
MATERIAL AND METHODS

The fossil material was collected from the fine sediments occurring at the

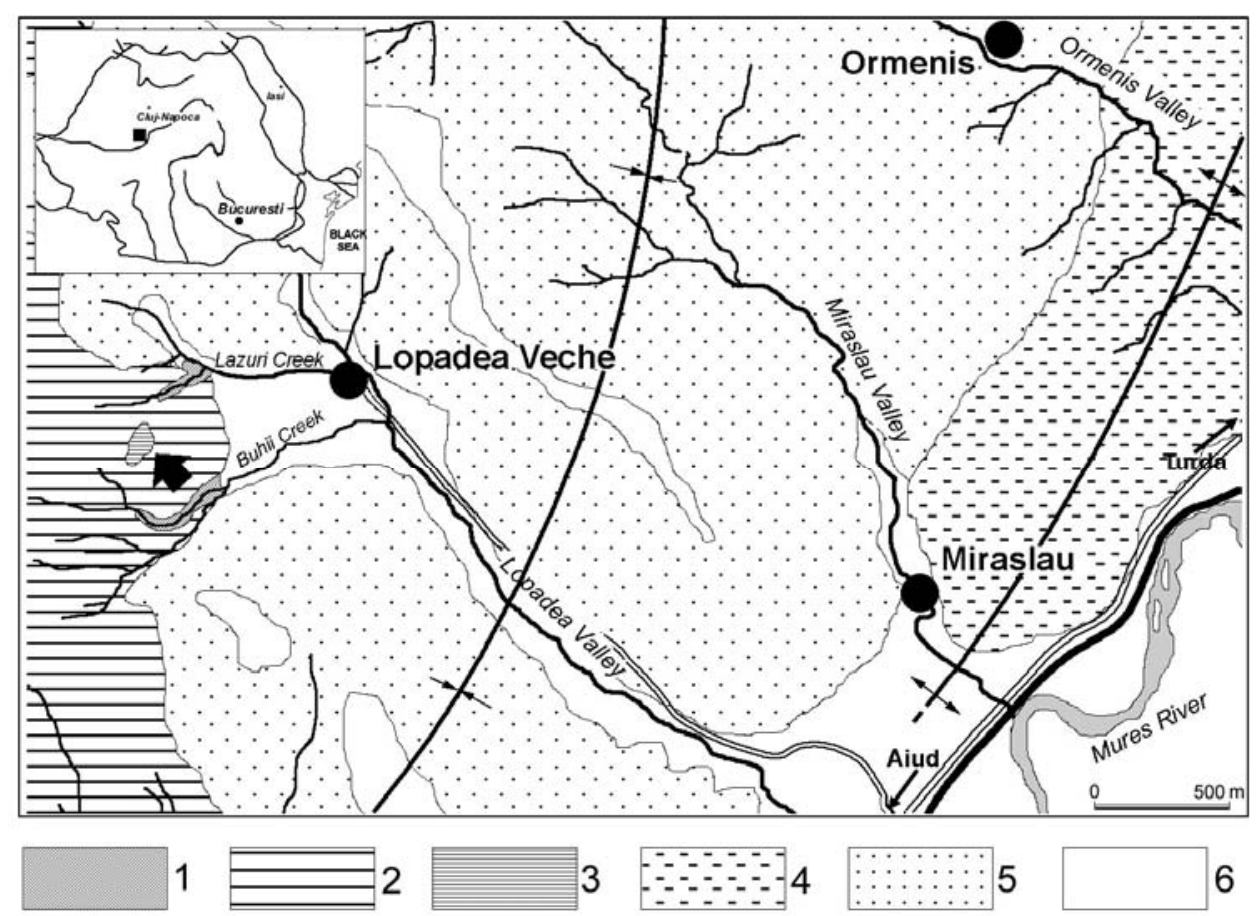

Figure 1 - Location of the studied area: 1. Jurassic volcanic rocks; 2. Gârbova de Sus Formation; 3. Cheia Formation; 4. Măhăceni Formation; 5. Lopadea Formation; 6. Quaternary deposits; black arrow - location of the studied section (based on Bucur \& Filipescu, 2001)

top of Gârbova de Sus Formation, at Lopadea Veche, Buhii Creek section.

The samples were processed by standard micropaleontological methods, using tap water, calgon and a 63- $\mu \mathrm{m}$ sieve. The fossil foraminifera were picked from entire $>63-\mu \mathrm{m}$ residue and the specimens were photographed using a DSM 940 Zeiss SEM microscope at University College London.

\section{SIGNIFICANCE OF FORAMINIFERA ASSEMBLAGE}

Processing of the micropaleontological samples revealed a well-preserved foraminifera assemblage, with both benthic and planktonik foraminifera. Very few other fossil groups, as ostracods and fragments of bivalves, are also present in the micropaleontologic residue. 
WIELICIAN FORAMINIFERA AT THE WESTERN BORDER OF THE TRANSYLVANIAN BASIN

\begin{tabular}{|c|c|c|c|}
\hline Species & Moravian & Wielician & Kossovian \\
\hline \begin{tabular}{|l|} 
Textularia mariae d'ORBIGNY \\
Psammolinqulina papillosa (NEUGEBOREN)
\end{tabular} & & & \\
\hline Martinottiella communis (d'ORBIGNY) & & & - \\
\hline Sigmoilinita tenuis (CZJZEK) & & & \\
\hline $\begin{array}{l}\text { Lenticulina inornata (d'ORBIGNY) } \\
\text { Guttulina communis d'ORBIGNY }\end{array}$ & & & \\
\hline Guttulina ovata d'ORBIGNY & "---" & $\ldots$ & \\
\hline Globulina punctata d'ORBIGNY & & 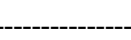 & \\
\hline Globorotalia transsylvanica POPESCU & & & \\
\hline Globoturborotalita woodi (JENKINS) & & & \\
\hline Globigerina bulloides d'ORBIGNY & & & \\
\hline Globigerina tarkhanensis SUBBOTINA \& CHUTZIEVA & & & \\
\hline Globigerinoides quadrilobatus (d'ORBIGNY) & & ---יני & \\
\hline $\begin{array}{l}\text { Globigerinoides bulloideus CRESCENTI } \\
\text { Islandiella punctata (REUSS) }\end{array}$ & & & \\
\hline Cassidulina laevigata d'ORBIGNY & & & \\
\hline $\begin{array}{l}\text { Bulimina elongata d'ORBIGNY } \\
\text { Bulimina subulata CUSHMAN \& PARKER }\end{array}$ & & & \\
\hline Uvigerina grilli SCHMID & & & \\
\hline $\begin{array}{l}\text { Uvigerina orbignyana CZJZEK. } \\
\text { Uvigerina pudica ŁUCZKOWSKA }\end{array}$ & & & \\
\hline $\begin{array}{l}\text { Uvigerina semiornata d'ORBIGNY } \\
\text { Uvigerina venusta FRANZENAU }\end{array}$ & & & \\
\hline Reussella spinulosa (REUSS) & & & \\
\hline Fursenkoina acuta (d'ORBIGNY) & & & \\
\hline Sphaeroidina bulloides d'ORBIGNY & & & \\
\hline Cibicidoides ungerianus (d'ORBIGNY) & & & \\
\hline Cibicidoides ornatus (CICHA \& ZAPLETALOVA) & & & \\
\hline Biapertorbis biaperturatus $\mathrm{PO}$ & $\cdots$ & 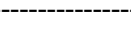 & \\
\hline Asterigerinata planorbis (d'ORBIGNY) & & & \\
\hline Pullenia bulloides (d'ORBIGNY) & -- & & \\
\hline Melonis pompilioides (FICHTEL \& MOLL) & & & \\
\hline Heterolepa dutemplei (d'ORBIGNY) & 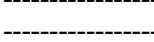 & & \\
\hline Porosononion granosum (d'ORBIGNY) & --. & & \\
\hline Elphidium fichtelianum (d'ORBIGNY) & & & \\
\hline
\end{tabular}

Figure 2. Badenian stratigraphic range of the common foraminifera species present at the top of Gârbova de Sus Formation (ranges based on Cicha et al., 1998; Popescu, 1998)

Composition of the foraminifera assemblage and range of the most frequent taxa within Miocene is presented in Fig. 2. Although the large majority of the taxa show a wider stratigraphic range, the presence of several important stratigraphic markers can also be noticed. Several species start their range within the Wielician and continue into the Kossovian, but the age of our assemblage can not be Kossovian because the well-known Wielician gypsum covers it. 
Representatives of the subtropical group of Candorbulina are absent in the studied assemblage, being replaced by planktonics that probably supported slightly colder waters. The cooling tendency was recorded even from the middle part of the formation, reflected by a constant regressive character of the sedimentation, reduction of faunal diversity, and disappearance of subtropical forms.

Another deepening of the environment was recorded at the top of the formation, within the studied foraminifera assemblage. It is suggested by a new invasion of planktonic and deeper benthic taxa.

Most of the planktonics show a wide range, except for Globorotalia transsylvanica, which is considered by Popescu (1998) as a typical species for the Late Langhian Globoturborotalita druryi / Globorotalia transsylvanica Concurrent Range Zone. Its stratigraphic range is considered to be restricted to the Uppermost Moravian and Wielician in the Central Paratethys.

Concurrent ranges of the benthics also suggest the Wielician age, although not all the index taxa are present. However, several taxa have a typical range or abundance within Wielician. The case of Uvigerina species is very suggestive for their biostratigraphic value (e.g. Uvigerina orbignyana CZJZEK, Uvigerina pudica ŁUCZKOWSKA, Uvigerina venusta FRANZENAU). We can conclude that benthic taxa belong to Uvigerina orbignyana / Pseudotriplasia minuta Biozone of Popescu (1998).

Benthic infaunal morphogroups (tapered, cylindrical and spherical) also suggest depths of several hundreds of meters. In my opinion, the occurrence of this new type of benthic fauna do not suggest a cooling event, as previously considered, but a migration of deeper taxa, who lived in colder waters. The presence of new planktonic and deeper benthic taxa seems to be related to a new transgressive event, as also confirmed by sedimentologic pattern. This event might be correlated with the start of a new global cycle, probably the $3^{\text {rd }}$ order 2.4 cycle (TB2 supercycle) of Haq (1993). A correlation with the mentioned event was possible by calibration of Globoturborotalita druryi / Globorotalia transsylvanica Biozone to the lower M7 Zone of the standard Neogene chart, as shown by Popescu (1998). The same author presented a different correlation between standard (Berggren et al., 1995) and Paratethian (Cicha et al., 1998) charts, by tracing the M6-M7 (N9N10) boundary within the Uppermost Langhian.

Probably the Wielician foraminifera fauna from the top of Gârbova de Sus Formation, together with other similar faunas identified in Romania (Popescu, 1978; Gheorghian, 1975) and Paratethyan area (Reuss, 1867), represent a proof for the last transgressive event that advanced from the Mediterranean towards the Central Paratethys. This was followed by the well-known particular evolution of the Paratethyan area, apart from the Mediterranean realm.

\section{CONCLUSIONS}

Recently discovered foraminifera fauna at the top of the Gârbova de Sus Formation allowed the extension of its known age up to Wielician (Uppermost Langhian).

Planktonic and deeper benthic species found in the fine sediments situated above the shallow-water carbonate sequence document a new transgressive event, probably the last one coming from the Mediterranean. This event might be correlated 
with the beginning of 2.4 cycle. Tectonic events in the Carpathian realm isolated the area only during the second part of Wielician, leading to deposition of the salt and gypsum deposits.

\section{Acknowledgements}

I would like to gratefully thank Dr. Michael A. Kaminski (University College London) and NERC-ODP for supporting the SEM work.

\section{REFERENCES}

Berggren, W.A., Kent, D.W., Swisher, C.C., Aubry, M.-P., 1995 - A revised Cenozoic Geochronology and Chronostratigraphy. Geochronology, Time Scales, and Global Stratigraphic Correlations: SEPM Special Publication, 54, 129-212.

Bucur, I.I., Filipescu, S., 1994 - Middle Miocene Red Algae from the Transylvanian Basin (Romania). Beiträge zur Paläontologie, 19, 39-47. Wien.

Bucur, I.I., Filipescu, S., 2001 - Middle Miocene Red Algae from the Western Border of the Transylvanian Basin. In: Bucur, I.I. et al. (eds.) Algae and Carbonate Platforms in the Western Part of Romania. Field trip Guide Book $\left(4^{\text {th }}\right.$ Regional Meeting of IFAA ClujNapoca, August 29 - September 5, 2001. 179-189. Cluj-Napoca.

Cicha, I., Rögl, F., Rupp, C., Ctyroka, J., 1998 - Oligocene - Miocene foraminifera of the Central Paratethys. Abhandlungen der Senckenbergischen Naturforschenden Gesellschaft 549, 325pp. Frankfurt a. M.

Filipescu, S., 1996 - Stratigraphy of the Neogene from the Western Border of the Transylvanian Basin. Studia Universitatis Babeş-Bolyai. Geologia XLI/2, 3-78. Cluj-Napoca.

Filipescu, S., Girbacea, R., 1994 - Stratigraphic remarks on the Middle Miocene Deposits from Gîrbova de Sus (Transylvanian Basin, Romania). Studia Universitatis Babeş-Bolyai. Geologia XXXIX/1-2, 275-286. Cluj-Napoca.

Gheorghian, D., 1975. Coupe d'Apold: Eocene, Badénien, Sarmatien. In: Bombiță, Gh. (ed.) $14^{\text {th }}$ European Micropaleontological Colloquium Guide. Institutul de Geologie şi Geofizică. 175-178. Bucureşti

Haq, B.U., 1993 - Deep-sea response to eustatic change and significance of gas hydrates for continental margin stratigraphy. In: Posamentier, H.W. et al. Sequence stratigraphy and facies associations. Spec. Publs. Int. Ass. Sediment. 18, 93-106. Blackwell.

Pávay - Vajna, F., 1910 - Die geologischen Verhältnisse der Umgebung von Olah - Lapad. Földtany Közlöny XL, 420-434. Budapest.

Popescu, Gh., 1978 - Date preliminare asupra Miocenului mediu din împrejurimile Hunedoarei. Dări de Seamă Institutul de Geologie şi Geofizică 63 (3), 63-79. Bucureşti.

Popescu, Gh., 1998 - Stratigrafia Miocenului mediu marin din Paratethysul Central (sectorul românesc). Buletinul Societății Paleontologilor din România, nr. 4, 13-19. Bucureşti.

Reuss, A.E., 1867 - Die fossile Fauna der Steinsalzablagerung von Wieliczka in Galizien. Sitzber. k. Akad. Wiss. Math.-naturw., LV/1, 17-182. Wien.

Şuraru, N., 1992 - Biostratigraphische Erwägungen über das obere Badenien aus dem Gebiet von Lopadea Veche (Kreis Alba) - Pietroasa (Kreis Cluj). Studia Universitatis BabeşBolyai, Geologia. XXXVII / 2, 49-63. Cluj-Napoca. 


\section{PLATES}

Plate I - Foraminifera at the top of Buhii Creek section (scale bar $=100 \mu \mathrm{m}$ )

1. Martinottiella communis (d'ORBIGNY)

2. Sigmoilinita tenuis (CZJZEK)

3. Lenticulina inornata (d'ORBIGNY)

4. Guttulina communis d'ORBIGNY

5. Guttulina ovata d'ORBIGNY

6,7. Globulina gibba d'ORBIGNY: 6. with fistulous chambers; 8. common

8. Globulina punctata d'ORBIGNY

9. Bulimina elongata d'ORBIGNY

10. Bulimina subulata CUSHMAN \& PARKER, twins

11. Cassidulina laevigata d'ORBIGNY

12. Fursenkoina acuta (d'ORBIGNY)

13. Reussella spinulosa (REUSS)

14. Stilostomella sp.

15. Sphaeroidina bulloides d'ORBIGNY

16. Melonis pompilioides (FICHTEL \& MOLL)

Plate II - Foraminifera at the top of Buhii Creek section (scale bar=100 $\mu \mathrm{m}$ )

1. Globigerina praebulloides BLOW

2,3. Globigerina bulloides d'ORBIGNY

4. Globigerina diplostoma REUSS

5,6. Globigerina tarkhanensis SUBBOTINA \& CHUTZIEVA

7. Globorotalia transsylvanica POPESCU

8. Globoturborotalita woodi (JENKINS)

9,10. Asterigerinata planorbis (d'ORBIGNY)

11,12. Biapertorbis biaperturatus POKORNY

Plate III - Foraminifera at the top of Buhii Creek section (scale bar=100 $\mu \mathrm{m}$ )

1,2 Uvigerina orbignyana CZJZEK. (2. detail of surface)

3,4. Uvigerina pudica LUCZKOWSKA (4. detail of surface)

5,6. Uvigerina semiornata d'ORBIGNY (6. detail of surface)

7. Uvigerina venusta FRANZENAU

8. Pullenia bulloides (d'ORBIGNY)

9,10 . Hanzawaia boueana (d'ORBIGNY)

11. Porosononion granosum (d'ORBIGNY)

12,13. Heterolepa dutemplei (d'ORBIGNY)

14. Elphidium fichtelianum (d'ORBIGNY) 
Plate I

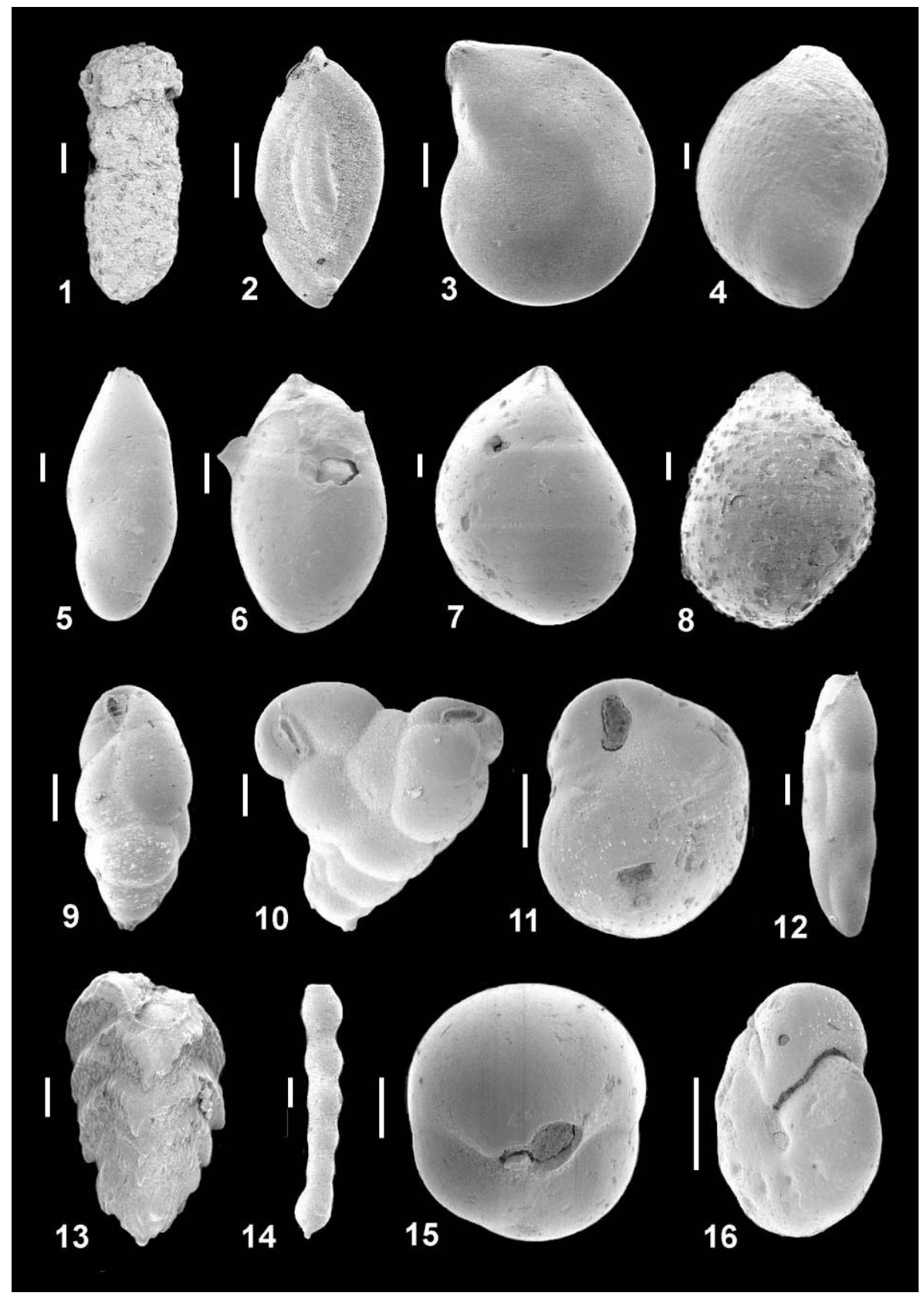


Plate II

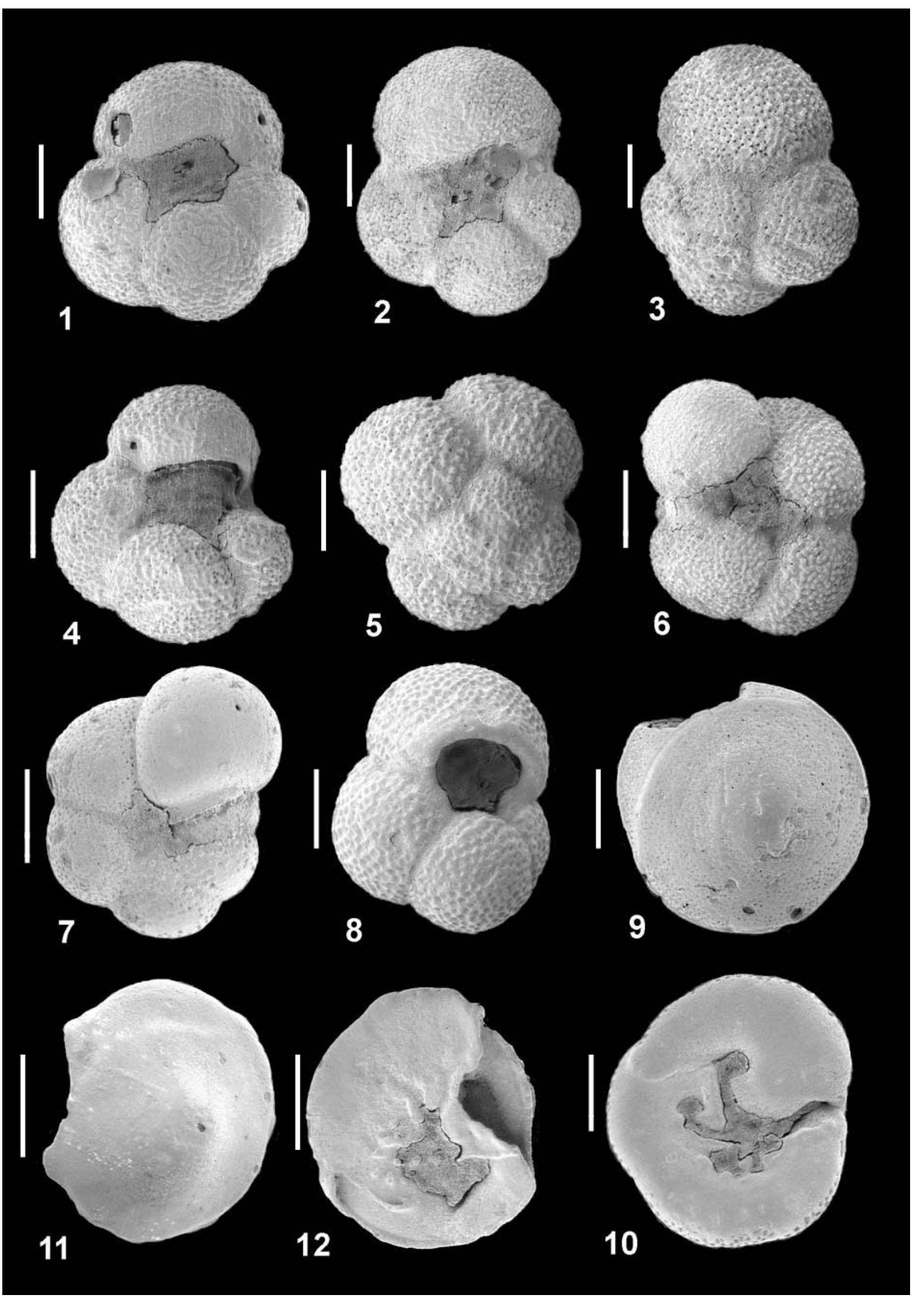




\section{Plate III}
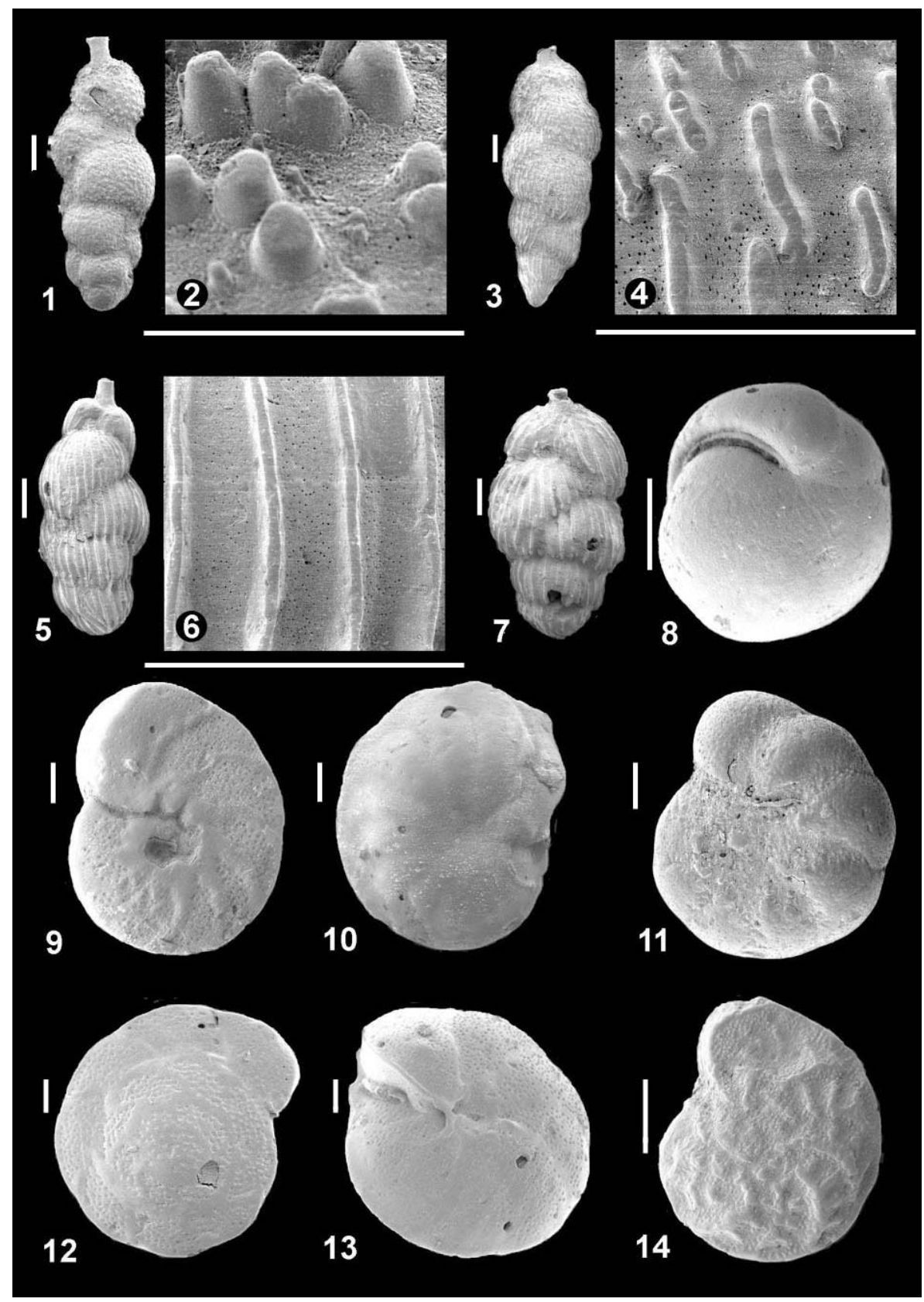